\title{
Social Return On Investment (SROI) Analysis in Empowering Pepper Farmers Program in Petaling Banjar Village
}

\author{
Yosa Novia Dewi ${ }^{1}$, Jamilullah ${ }^{2}$, Elis Trisnawati ${ }^{3}$, Euis Intan Anovani ${ }^{4}$, Khidayatul Munawwaroh ${ }^{5}$,Firdaus ${ }^{6}$ \\ ${ }^{1}$ FKIP UPI Yptk Padang, Lubuk Begalung on XX, Padang \\ ${ }^{2,3}$ Manajemen Pendidikan STAI Al Qudwah, Beringin on 12, Depok \\ ${ }^{4}$ BSC Consulting (PT. Batata Sistem Caraka), TB Simatupang on 1, Jakarta \\ ${ }^{5}$ FKIP Unbari, Slamet Riyadi on 1, Jambi \\ ${ }^{6} P$ T. Refined Bangka Tin, Kawasan Industri Jelitik, Bangka \\ *E-mail: elis.trisnawati26@gmail.com

\begin{tabular}{ll}
\hline Artikel submit & : September, 10.2021 \\
Artikel review & : November, 12, 2021 \\
Artikel accepted & : December, 12.2021 \\
\hline
\end{tabular}

\begin{abstract}
Pepper farmers in Petaling Banjar Village, Mendo Barat District, Bangka Regency, Bangka Belitung Islands Province are the Pepper Farmer Empowerment Program members. That program is a community group assisted by the CSR (Corporate Social Responsibility) of PT Refined Bangka Tin (here and after called PT RBT). As a social investment, the CSR activities in the long term will bring business returns in the form of profits for the company. Social Return on Investment (SROI) is a method used to measure the social impact of CSR activities that does not only calculate the value of profits in the form of money. In addition, it also includes a broader concept that includes social, economic, and environmental values. This study involved representatives of crucial stakeholders consisting of 10 pepper farmers, six general public, one community leader, and two people from the Petaling Banjar village government. Data were collected using in-depth interview techniques, Focus Group Discussion (FGD), field observations, and the use of secondary data from documentation of PT RBT's CSR program. The results showed that the overall SROI value was 1.76. Thus, it indicated that every 1 IDR invested could generate a benefit value of 1.76 IDR. In conclusion, the program is socially feasible to implement.
\end{abstract}

Keywords: Social Return on Investment (SROI), Corporate Social Responsibility (CSR), the impact of social investment, pepper farmers

\section{Abstrak}

Petani Lada di Desa Petaling Banjar, Kecamatan Mendo Barat, Kabupaten Bangka, Provinsi, Kepulauan Bangka Belitung merupakan anggota Program Pemberdayaan Petani Lada. Program tersebut merupakan kelompok masyarakat binaan CSR (Corporate Social Responsibility) PT Refined Bangka Tin (selanjutnya disebut PT RBT). Sebagai investasi sosial, kegiatan CSR dalam jangka panjang akan membawa keuntungan bisnis berupa keuntungan bagi perusahaan. Social Return on Investment (SROI) merupakan metode yang digunakan untuk mengukur dampak sosial dari kegiatan CSR yang tidak hanya menghitung nilai keuntungan berupa uang. Selain itu, juga mencakup konsep yang lebih luas yang mencakup nilai-nilai sosial, ekonomi, dan lingkungan. Penelitian ini melibatkan perwakilan pemangku kepentingan penting yang terdiri dari 10 petani lada, enam masyarakat umum, satu tokoh masyarakat, dan dua orang dari pemerintah desa Petaling Banjar. Pengumpulan data dilakukan dengan teknik wawancara mendalam, Focus Group Discussion (FGD), observasi lapangan, dan penggunaan data sekunder berupa dokumentasi program CSR PT RBT. Hasil penelitian menunjukkan bahwa nilai SROI secara keseluruhan adalah 1,76. Dengan demikian, menunjukkan bahwa setiap 1 Rupiah yang diinvestasikan dapat menghasilkan nilai manfaat sebesar $\operatorname{Rp} 1,76$. Kesimpulannya, program ini layak secara sosial untuk dilaksanakan.

Kata kunci: Social Return on Investment (SROI), Corporate Social Responsibility (CSR), dampak investasi sosial, petani lada

Social Return On Investment (SROI) Analysis in Empowering Pepper Farmers Program in Petaling Banjar Village 


\section{INTRODUCTION}

According to Pranoto \& Yusuf (2014), Corporate Social Responsibility (CSR) is generally not only interpreted as a charitable or voluntary carried out by the company. However, the new CSR paradigm leads to a company's commitment to carrying out responsibilities or feedback to the community and the environment also sustainable independent economic development. Sustainable CSR programs should create a more prosperous and independent community life (Astri, 2012).

The strategic implementation of CSR in community development is a social investment approach for companies. Therefore, there is an interest in providing benefits to companies and stakeholders, especially beneficiaries, and focusing on vulnerable groups in society (Jalal and Kurniawan, 2013).

All companies must implement CSR activities to maximize profit for capital owners or shareholders and benefit the community, particularly the surrounding community. Various social, economic, and environmental impacts arising from establishing an industrial area require companies to be responsible to the public through noticeable activities (Budiarti and Raharjo, 2014).

\section{GENERAL DESCRIPTION OF THE COMMUNITY, PROBLEMS, AND TARGET SOLUTIONS}

\section{General description}

Pepper farmers in Petaling Banjar Village, Mendo Barat District, Bangka Regency, Bangka Belitung Islands Province are the Pepper Farmer Empowerment Program members. Pepper Farmer Empowerment Program is a community group assisted by the CSR of PT Refined Bangka Tin (here and after called PT RBT). The CSR of PT RBT has empowered about 25 people in the community through the pepper farmer empowerment program. The program has been implemented since 2019 and is planned until 2023. The program aims to improve the hygiene quality of pepper while increasing the welfare of the target community. The particular goal is the increased income of direct beneficiaries, which is expected more than the provincial minimum wage of the Bangka Belitung Islands.

\section{Problem}

According to Marnelly (2012), effective community empowerment makes people empowered, dynamic, and adaptive to changes in their environment. The community should have better access to appropriate technology, broaden-mind, global mindedness, and empathy for outsiders.

The evaluation implementation in the pepper farmer empowerment program was in the strengthening stage. At the end of the program, the pepper farmer empowerment community is expected to be empowered to utilize all the surrounding resources (technology, knowledge, productive businesses, institutions, and networks). So they can be more prosperous because they get income more than the provincial minimum wage.

\section{Target solution}

Based on the previous explanation, The CSR of PT RBT needs to measure the impact of the social investments. The excellent performance evaluation of a corporation's CSR program improves its position towards its stakeholders (Gauthier, 2005). Technically, program performance evaluation is an obligation of the company management to see how accurate the goals are and how much the achievement in output or program result (Buchholtz, Amason and Rutherford, 1999).

\section{METHOD}

Social Return On Investment (SROI) is a benchmark to help organizations understand and manage the social, environmental, and economic value that they generate. Therefore, SROI not only calculates the value

Social Return On Investment (SROI) Analysis in Empowering Pepper Farmers Program in Petaling Banjar Village 
but also reduces ecological inequality and degradation. Besides, SROI can improve community welfare by including social and environmental costs and economic costs and benefits. SROI analysis can change the increased value of impacts based on selected indicators to determine economic, social, and environmental welfare into currency values (Silalahi, Santoso, \& Suliantoro, 2018).

The SROI concept is not new, pioneered in America in the early 1990s, developed in England in 2008. Experts in England (Lawlor et al., 2012) propose 7 SROI principles in building a framework, namely: (1) Involve the stakeholders, (2) Understand what the changes are, (3) Value essential things, (4) Include obvious material, (5) Avoid excessive claims, (6) Must be transparent, (7) Verify the results.

The impact assessment of the pepper farmer empowerment program in Petaling Banjar Village involved respondents who were representatives of stakeholders, consisting of 10 pepper farmers, six people from the general public, one community leader, and two people from the village government. The data were collected from in-depth interview techniques, Focus Group Discussion (FGD), field observations, and the use of secondary data from documentation of PT RBT's CSR program. Judgment was based on references from standard documents, government regulations, research results, community consensus, and examples of similar events according to the existing local context. Furthermore, the data were grouped and analyzed to get the calculation of the impact value and its financial value to get the present value.

NPV [Net Present Value $]=[$ Present value of benefits $]-$ Value of investments $]$

The data obtained were then processed to calculate the SROI ratio as follows:

SROI Ratio $=\underline{\text { Present Value }}$

Value of Input

The evaluative calculation was done based on program achievements and some impacts that stakeholders have stated through in-depth interviews and FGDs. At the same time, the projection calculation (forecast) was based on harvest trends, business development planning, and pepper farmers' commitment to using the infrastructure program. The value projection was attempted to be as close and reasonable as possible by providing assumptions and examples of similar things or using standards in the community according to the context of the program.

\section{RESULTS AND DISCUSSION}

Based on the stakeholder mapping of the pepper farmer empowerment program or beneficiaries in Petaling Banjar Village, there were two categories: administrators and members of pepper farmer groups also the local communities. The following table contains a description of the impact mapping and monetization approach that has been implemented to obtain the value of social, economic, and technological impacts of the program.

Table 1. Stakeholder Mapping, Impact, and Monetization of Pepper Farmers Empowerment Program

\begin{tabular}{ccccc}
\hline Num IMPACTS & CALCULATION APPROACH & $\begin{array}{c}\text { MONETIZATION } \\
\text { APPROACH }\end{array}$ & $\begin{array}{c}\text { INTERVIEW } \\
\text { RESULTS AND } \\
\text { SECONDARY } \\
\text { DATA }\end{array}$ \\
\hline
\end{tabular}

1

1.1 The decrease in losing income risk of the pepper farmer group members due to immersion in ditches

\section{Administrators and pepper farmer group members}

Calculation of estimated clean pepper by $20 \%$ of a sack. 1 sack $=10$ kilograms $\times 20 \%=$ 2 kilograms of risk in losing pepper when immersed. $10 \%$ of sacks submerged.
Multiply the assumed amount of pepper lost by the per sack of pepper.

The price of $1 \mathrm{~kg}$ dried pepper per sack :

The year 2019: 60,000 IDR The year 2021
The year 2019: $52,500,000$ IDR

The year 2020: 41,400,000 IDR

Social Return On Investment (SROI) Analysis in Empowering Pepper Farmers Program in Petaling Banjar Village

Yosa Novia Dewi, Jamilullah . Elis Trisnawati, Euis Intan Anovani, Khidayatul Munawwaroh,Firdaus 


\begin{tabular}{|c|c|c|c|c|}
\hline Num & IMPACTS & CALCULATION APPROACH & $\begin{array}{l}\text { MONETIZATION } \\
\text { APPROACH }\end{array}$ & $\begin{array}{c}\text { INTERVIEW } \\
\text { RESULTS AND } \\
\text { SECONDARY } \\
\text { DATA }\end{array}$ \\
\hline & & $\begin{array}{l}\text { The Year } 2019 \\
525 \times 10 \%=52,5 \text { sacks } \\
\text { The year } 2020\end{array}$ & $\begin{array}{l}\text { The year 2020: } 60,000 \text { IDR } \\
\text { The year 2021: } 100,000 \text { IDR }\end{array}$ & Rp 47,000,000 IDR \\
\hline
\end{tabular}

1.2 Save the cost of pepper washing

1.3 The increased productive time for members of pepper farmer groups

1.4 The increased pepper hygiene
$414 \times 10 \%=41,4$ sacks

Yar 2021

$470 \times 10 \%=47$ sacks

Calculation of estimated clean pepper by $20 \%$ of a sack.

1 sack $=10$ kilograms $\times 20 \%=$

2 kilograms

the number of days and the cost of the pepper washing process

The year 2019: 14 days

The year 2020: 12 days

The year 2021: 13 days

Calculation of estimated clean pepper by $20 \%$ of a sack.

1 sack $=10$ kilograms $\times 20 \%=$

2 kilograms

the number of days for plant and field care from the productive time generated after the program

The year 2019: 14 days

The year 2020: 12 days

The year 2021: 13 days

Calculation of estimated clean

pepper by $20 \%$ of a sack.

1 sack $=10$ kilograms $\times 20 \%=$

2 kilograms

The year 2019: 1050 kilograms

The year 2020: 828 kilograms

The year 2021: 940 kilograms

1.5 The decreased risk in loss/damage of pepper agricultural commodities when dried

1.6 Farmers' time becomes more productive because of the drying house
Calculation of losing estimation of pepper loss/damage dried as around $10 \%$ of a sack.

1 sack $=10 \mathrm{~kg} \times 10 \%=$

1 kilogram

The year 2021: 470 kilograms

Calculation of the days before there is a drying house according to the amount of rice/corn dried in the drying house, where $100 \mathrm{~kg}$ takes an average of 3 days.

The year 2021: 141 days multiplying the number of days by the labor wage per person/day.

The labor wage per

person/day

The year 2019: 150,000 IDR

The year 2020: 150,000 IDR

The year 2021: 150,000 IDR

multiplying the number of opportunity days for plants and fields by the wages of labor to maintain plants \& fields per day, 100,000 IDR (The year 2019, 2020, 2021)

multiplying the assumed quantity of clean pepper by the price difference grade a and grade b, 20,000 IDR (2019, 2020, 2021)

multiplying the assumed risk of loss/damage of pepper when dried by the price of pepper.

The year 2021: 100,000 IDR

multiplying the number of days by the wages of labor per day.

the wages of labor per day The year 2021: 100,000 IDR
The year 2019: 2,100,000 IDR

The year 2020 1,800,000 IDR The year 2021

$1,950,000 \mathrm{IDR}$

The year 2019: 1,400,000 IDR The year 2020: 1,200,000 IDR

The year 2021: $1,300,000$ IDR

The year 2019: 21,000,000 IDR The year 2020: 16,560,000 IDR The year 2021: $18,800,000$ IDR

The year 2021: 47,000,000 IDR

The year 2021: 14,100,000 IDR

Social Return On Investment (SROI) Analysis in Empowering Pepper Farmers Program in Petaling Banjar Village 


\begin{tabular}{|c|c|c|c|c|}
\hline Num & IMPACTS & CALCULATION APPROACH & $\begin{array}{c}\text { MONETIZATION } \\
\text { APPROACH }\end{array}$ & $\begin{array}{c}\text { INTERVIEW } \\
\text { RESULTS AND } \\
\text { SECONDARY } \\
\text { DATA }\end{array}$ \\
\hline 2.1 & $\begin{array}{l}\text { The decreased risk } \\
\text { in loss/damage of } \\
\text { pepper } \\
\text { agricultural } \\
\text { commodities } \\
\text { when dried }\end{array}$ & $\begin{array}{l}\text { Calculation of the estimation of } \\
\text { loss/damage of the rice/corn } \\
\text { loss/damage when dried up to } \\
\text { 10\%. } \\
\text { The year 2020: } 50 \text { kilograms } \\
\text { The year 2021: } 50 \text { kilograms }\end{array}$ & $\begin{array}{l}\text { multiplying the estimated } \\
\text { loss/damage of rice/corn by } \\
\text { the price of rice/maize per } \\
\text { kilogram } \\
\text { The year 2020: } 10,000 \text { IDR } \\
\text { The year 2021: } 10,000 \text { IDR }\end{array}$ & $\begin{array}{l}\text { The year 2020: } \\
\text { 500,000 IDR } \\
\text { The year 2021: } \\
500,000 \text { IDR }\end{array}$ \\
\hline 2.2 & $\begin{array}{l}\text { The increased } \\
\text { productive time } \\
\text { for members of } \\
\text { pepper farmer } \\
\text { groups }\end{array}$ & $\begin{array}{l}\text { Calculation of the days before } \\
\text { there is a drying house according } \\
\text { to the amount of rice/corn dried in } \\
\text { the drying house, where } 100 \mathrm{~kg} \\
\text { takes an average of } 3 \text { days. } \\
\text { The year 2020: } 15 \text { days } \\
\text { The year 2021: } 15 \text { days }\end{array}$ & $\begin{array}{l}\text { multiplying the number of } \\
\text { days by the wages of labor } \\
\text { per day. } \\
\text { The wages of labor per day } \\
\text { The year 2020: } 100,000 \text { IDR } \\
\text { The year 2021: } 100,000 \text { IDR }\end{array}$ & $\begin{array}{l}\text { The year } 2020 \\
\text { Rp } 1.500 .000 \\
\text { The year 2021: } \\
1,500,000 \text { IDR }\end{array}$ \\
\hline
\end{tabular}

The next stage was calculating all the information and estimation into financial value. The resulting benefit values would be converted into one value in present value by considering changes in currency values

Table 2. Calculation of Input and Outcome Values

\begin{tabular}{|c|c|c|c|c|c|}
\hline & DESCRIPTION & 2019 (IDR) & 2020 (IDR) & 2021 (IDR) & Total (IDR) \\
\hline \multirow[t]{3}{*}{$\mathbf{I}$} & INPUT & & & & \\
\hline & CSR PT RBT & $70,000,000$ & $110,000,000$ & $100,000,000$ & $280,000,000$ \\
\hline & Total & $70,000,000$ & $110,000,000$ & $50,000,000$ & $280,000,000$ \\
\hline \multirow{9}{*}{$\begin{array}{l}\text { II } \\
1 .\end{array}$} & OUTCOME & & & & \\
\hline & $\begin{array}{l}\text { Administrators \& Pepper Farmer } \\
\text { Group }\end{array}$ & & & & \\
\hline & $\begin{array}{l}\text { The decrease in losing income risk of the } \\
\text { pepper farmer group members due to } \\
\text { immersion in ditches }\end{array}$ & $52,500,000$ & $41,400,000$ & $47,000,000$ & $140,900,000$ \\
\hline & Save the cost of pepper washing & $2,100,000$ & $1,800,000$ & $1,950,000$ & $5,850,000$ \\
\hline & $\begin{array}{l}\text { The increase of productive time for pepper } \\
\text { farmer group members }\end{array}$ & $1,400,000$ & 000 & $1,300,000$ & $3,900,000$ \\
\hline & $\begin{array}{l}\text { The increase of pepper hygiene quality } \\
\text { The decrease of loosing and damage risk }\end{array}$ & $10,500,000$ & $8,280,000$ & $, 400,000$ & $28,180,000$ \\
\hline & $\begin{array}{l}\text { of pepper agricultural commodities when } \\
\text { dried }\end{array}$ & & & $47,000,000$ & $47,000,000$ \\
\hline & $\begin{array}{l}\text { Farmers' time becomes more productive } \\
\text { because of the drying house }\end{array}$ & & & $14,100,000$ & $14,100,000$ \\
\hline & $\begin{array}{l}\text { The increase of pride/happiness in farming } \\
\text { the pepper } \\
\text { Surrounding Community }\end{array}$ & & & $300,000,000$ & $300,000,000$ \\
\hline \multirow{3}{*}{2} & $\begin{array}{l}\text { The decrease of loss and damage risk in } \\
\text { pepper agricultural commodities (rice, } \\
\text { corn) }\end{array}$ & & & 500,000 & $1,000,000$ \\
\hline & $\begin{array}{c}\text { Farmers have a more productive time } \\
\text { TOTAL OUTCOME }\end{array}$ & $66,500,000$ & $\begin{array}{r}1,500,000 \\
54,680,000\end{array}$ & $\begin{array}{r}1,500,000 \\
\end{array}$ & $\begin{array}{r}3,000,000 \\
543,030000\end{array}$ \\
\hline & & & & $42 L, / 50,000$ & $343,930,000$ \\
\hline
\end{tabular}

Table 3. Calculation of Present Value and SROI

Social Return On Investment (SROI) Analysis in Empowering Pepper Farmers Program in Petaling Banjar Village 


\begin{tabular}{lrrrr}
\hline TOTAL INPUT & $70,000,000$ & $110,000,000$ & $100,000,000$ & $280,000,000$ \\
\hline TOTAL OUTCOME & $66,500,000$ & $54,680,000$ & $422,750,000$ & $543,930,000$ \\
Deadweight & - & - & - & - \\
Attribution & - & - & - & - \\
Drop Off & - & - & - & - \\
Total outcome Per year after dicount & $66,500,000$ & $54,680,000$ & $422,750,000$ & $543,930,000$ \\
Present value 2019 (r=5.63), 2020 $(\mathrm{r}=4.23)$, & $62,955,600$ & $50,331,866$ & $380,413,479$ & $493,700,944$ \\
$2021(\mathrm{r}=3.58)$ & $\mathbf{0 . 9 0}$ & $\mathbf{0 . 4 6}$ & $\mathbf{3 . 8 0}$ & $\mathbf{1 . 7 6}$ \\
SROI & & & & \\
\hline
\end{tabular}

Generally, since implementing the pepper farmer empowerment program in 2019, 2020, and 2021, the SROI value tended not to fluctuate. In 2019 and 2021, it managed to increase by more than (Ristanti, A. D., \& Masita, E. D. 2021). It means that every 1 IDR invested has a benefit of more than 1 IDR. Thus, the program was socially feasible to implement even though in 2020, the SROI value was less than 1 due to: 1) the pepper harvest reduction, 2) the minimum use of drying house infrastructure because the facilities had just been completed after the period of the pepper harvest period. Masita,( E. D., Isnaini, Y., \& Lestari, P. C. A. 2021) The most significant proportion of benefits, respectively, lied in the decrease in losing income risk of the pepper farmer group members due to immersion in ditches, the high pepper hygiene quality, and decreased loss and damage risk in pepper agricultural commodities when dried. From a stakeholder perspective, the biggest beneficiaries of this program were the administrators and members of the pepper farmer groups. The direct beneficiaries received a benefit of $268,110,000$ IDR or $98.5 \%$ of the total program benefits. Meanwhile, the local community only received a benefit of $4,000,000$ IDR or $1.5 \%$ of the total program benefits. (Masita, E. D., Maimunah, S., \& Abidah, S. N. 2019).

\section{CONCLUSIONS AND SUGGESTIONS}

The SROI value of the pepper farmer empowerment program assisted by PT RBT's CSR from 2019 to 2021 was 1.76 . Thus, it indicated that every 1 IDR invested could generate a benefit value of 1.76 IDR. In conclusion, the program is socially feasible to implement. The program benefits could be improved for the main target groups, the local community, and other stakeholders. Efforts to ensure the sustainability of the program's in the future are:

1. Capacity building program for the main target groups, especially regarding the management of pepper cultivation, starting from planting, care, post-harvest, processing, packaging, and product marketing.

2. Role strengthening of the Petaling Banjar pepper farmer cooperative in the community, especially in increasing the management and cooperative members' capacity to manage program funds, leadership, transparency, transaction, and cooperation contracts.

\section{REFERENCES}

Astri, H. (2012) "Pemanfaatan Corporate Social Responsibility Bagi Peningkatan Kualitas Hidup Manusia Indonesia," Aspirasi, 3, p. 163.

Buchholtz, A.K., Amason, A.C. and Rutherford, M.A. (1999) The Mediating Effect of Top Management Discretion and Values on Corporate Philanthropy. Business and Society.

Budiarti, M. and Raharjo, S.T. (2014) "Corporate Social Responsibility (CSR) Dari Sudut Pandang Perusahaan," Share Social Work Journal, 28.

298

Social Return On Investment (SROI) Analysis in Empowering Pepper Farmers Program in Petaling

Banjar Village

Yosa Novia Dewi , Jamilullah . Elis Trisnawati , Euis Intan Anovani, Khidayatul Munawwaroh,Firdaus 
Masita, E. D., Maimunah, S., \& Abidah, S. N. (2019). Pemanfaatan Rumah Keluarga Sebagai Kedasi (Kedai Support Asi) Menuju Zero Susu Formula Pada Bayi Usia 0-6 Bulan. Jurnal Pengabdian Masyarakat IPTEKS, 5(1), 13-21.

Masita, E. D., Isnaini, Y., \& Lestari, P. C. A. (2021, February). PEMBERDAYAAN EXS. NAPI REMAJA KECAMATAN KENJERAN. In Seminar Nasional ADPI Mengabdi Untuk Negeri (Vol. 2, No. 2, pp. 146-151).

Gauthier, C. (2005) "Measuring Corporate Social and Environmental Performance: The Extended Life-Cycle Assessment," Journal of Business Ethics, 199-206.

Jalal and Kurniawan, F. (2013) "Investasi Sosial: Perspektif CSR Strategis untuk Pengembangan Masyarakat oleh Perusahaan." Available at: https://socialinvestment.id/artikel/investasi-sosial-perspektif-csrstrategis-untuk-pengembangan-masyarakat-oleh-perusahaan/.

Lawlor, E. et al. (2012) A Guide to Social Return on.The SROI Network, Business and Society.

Marnelly, T.R. (2012) "Corporate Social Responsibility (CSR): Tinjauan Teori dan Praktek di Indonesia," Jurnal Aplikasi Bisnis, 59.

Ristanti, A. D., \& Masita, E. D. (2021). Peran Kader dalam Mendorong Pemberian Asi Di Masa Pandemi Covid-19. To Maega: Jurnal Pengabdian Masyarakat, 4(1), 47-54.

Social Return On Investment (SROI) Analysis in Empowering Pepper Farmers Program in Petaling

Banjar Village

Yosa Novia Dewi, Jamilullah . Elis Trisnawati, Euis Intan Anovani , Khidayatul Munawwaroh,Firdaus 